\title{
ANALISIS PERAN POLA ASUHAN DAN PROSES SOSIALISASI OLAHRAGA BELADIRI DITINJAU DARI PERSPEKTIF KESETARAAN GENDER
}

\author{
Berliana \\ FPOK Universitas Pendidikan Indonesia \\ email: berliana.rahely@yahoo.co.id
}

\begin{abstract}
Abstrak: Penelitian ini berangkat dari pemikiran bahwa peluang yang diberikan pada anak perempuan untuk melakukan aktivitas publik belum sepenuhnya. Keengganan orang tua memberikan izin kepada anak perempuan menggeluti cabang olahraga berat, masih dipengaruhi oleh konteks masyarakat dan budaya. Masalah pokok dan fokus kajian berkaitan dengan pola pengasuhan anak pada keluarga, klub, dan sekolah dalam menggiring mereka mengambil keputusan sebagai atlet dalam olahraga kompetitif. Sekaitan dengan itu, situs penelitian lapangan dilakukan pada atlet, keluarga, pelatih, dan sekolah, selain ditambah data yang digali dari suami, rekan tempat bekerja, dan lingkungan masyarakat. Observasi partisipasi sebagai upaya memotret data dilakukan peneliti selama enam bulan lama. Penelitian ini menyimpulkan bahwa pola asuh yang diterapkan pada anak perempuan akan menggiring mereka untuk menggeluti olahraga prestasi sejak kecil dan menumbuhkan kemandirian yang memperkokoh konteks pandangan perempuan terhadap dirinya sebagai sumberdaya manusia yang berkualitas.
\end{abstract}

\section{Kata Kunci: pola asuh, atlit perempuan, perspektif gender}

\section{AN ANALYSIS OF THE CHILD REARING PRACTICE AND THE MARTIAL ARTS SOCIALIZATION PROCESS VIEWED FROM THE GENDER EQUALITY PERSPECTIVE}

\begin{abstract}
This study started from the idea that girls were not given sufficient opportunities to do public activities. The parents' reluctance to give permission to their daughters to do heavy sports was influenced by the community's contexts and culture. The core problem and the focus of this study was related to the child rearing practice in the family, in the club, and in schools by encouraging the girls to make a decision as competitive sports athletes. Accordingly, the field study was focused on the athletes, the family, the coach, and schools. The data were also obtained from husbands, colleagues, and community environment. The researcher conducted participant observation for six months. The findings showed that the child rearing to girls led them to join competitive sports and this had developed their independence which strengthened their own perception on themselves as quality human resources.
\end{abstract}

Keywords: child rearing practice, female athletes, gender perspective

\section{PENDAHULUAN}

Permasalahan utama yang diungkap dalam penelitian ini adalah diskriminasi gender dalam olahraga prestasi, terutama olahraga yang mengundang citra laki-laki. Hal ini antara lain didukung oleh beberapa literatur yang menempatkan olahraga sebagai "a male domain" (Anderson, 2005). Bagi kaum laki-laki partisipasi olahraga dianggap sebagai aktivitas yang lebih "natural" dan secara signifikan didukung oleh pihak-pihak lain seperti orang tua dan sesama laki-laki. Sejak anak-anak telah ditanamkan keyakinan kepada anak laki-laki bahwa keberhasilan dalam kompetisi olahraga merupakan akses kunci untuk mendapatkan prestise dan harga diri (Messner \& Sabo, 1990, 2002). Sementara partisipasi wanita dalam aktivitas olahraga, meskipun bukti-bukti ditemukan bahwa olahraga tidak hanya cocok untuk lakilaki, tetapi juga untuk wanita, implementasinya masih terikat dengan dualisme tradisional dalam sistem budaya masyarakat yang menempatkan laki-laki dan karakteristik maskulinisasinya jauh lebih berpeluang untuk berpartisipasi dan berprestasi daripada wanita (Clasen, 2001). 
Padahal, telah banyak payung hukum yang dibuat terkait dengan kesetaraan gender, seperti konsep diskriminasi (discrimination) gender dalam The Convention on the Elimination of All Forms of Discrimination Against Women (CEDAW) yang menyuarakan kesetaraan antara laki-laki dan perempuan, konvensi untuk penghapusan segala bentuk diskriminasi terhadap perempuan (CEDAW, 2009) telah meratifikasi CEDAW yang dilakukan oleh 186 negara. Gagasan utamanya adalah membuat konsensus global untuk langkah konkret demi tercapai kesetaraan gender dan menghapus diskriminasi dalam segala bentuk. Selain itu, ia juga ditunjukkan Luisa (2011) dalam The Senate Committee on Foreign Relations Held Hearings on CEDAW in 1988, 1990, 1994, and 2002, and Reported It Favorably in 1994 and 2002. Hal ini dipertegas pula dalam UU No. 12 Tahun 2011, tentang Pembentukan Peraturan Perundang-Undangan yang menetapkan bahwa peraturan perundang-undangan harus mencerminkan antara lain asas kesamaan kedudukan dalam hukum dan pemerintahan. Olahraga juga diatur dalam Undang-Undang Republik Indonesia No. 3 Tahun 2005 Pasal 6 Bab IV tentang Sistem Keolahragaan Nasional (SKN) yang menegaskan mengenai hak yang dan pelayanan yang sama bagi setiap warga negara untuk berolahraga.

Aneka diskriminasi terhadap hak dan peranan kaum perempuan di Indonesia masih sering terjadi, seperti misalnya dalam bidang sosial, ekonomi, dan terlebih lagi di bidang politik. Kondisi ini masih merupakan masalah yang kompleks karena akar sejarah yang cukup panjang dan gejalanya jelas tampak dalam kehidupan sehari-hari. Fenomena ketimpangan sosial ini dapat diamati sejak berlangsung proses sosialisasi terhadap anak bayi perempuan di dalam keluarga, dan semakin kentara tatkala mereka sudah menginjak usia remaja dan dewasa. Kondisi yang mendiskriminasikan anak perempuan di Indonesia menyebabkan sempitnya kesempatan mereka untuk berperan di masyarakat dan dalam bidang olahraga apalagi sebagai pengambil keputusan. Hasil penelitian yang berkaitan dengan ini menyimpulkan bahwa has shown that the sport media in general construct men's competitions as more interesting, newsworthy and dramatithan women's competitions (Duncan and Messner, 2000; Knoppers and Anthonissen, 2003; Knoppers and Elling, 2001)

Tidak hanya kasus seperti yang dikemukakan di atas, kondisi lain yang menghambat kesempatan perempuan untuk memperoleh pendidikan formal, berawal dari budaya 'pingitan' dalam bentuk aneka pembatasan yang diperlakukan terhadap perempuan pada semua lapisan sosial di berbagai daerah di Indonesia. Budaya seperti ini bermula dari kecenderungan masyarakat untuk mendidik anak perempuan dengan perlakuan yang berbeda dengan lakilaki seperti tercermin dalam pola asuhan di lingkungan keluarga dan perlakuan ini merambah hingga pada kalangan masyarakat umum. Lutan (2004:90) mengemukakan bahwa fenomena ini disebut proses 'perambatan', yakni proses yang menjalar dari keluarga ke masyarakat luas yang terjadi pada semua faset kehidupan hingga keterlibatan anak perempuan dalam kegiatan berolahraga.

Persamaan hak antara laki-laki dan perempuan telah menjadi deklarasi yang merujuk kepada payung besar, yaitu Universal Declaration of Human Rights, yang diadopsi dan dicanangkan dalam Sidang Umum Persatuan Bangsa Bangsa (PBB) Community Forum (2006) yang antara lain berbunyi: "Whereas recognition of the inherent dignity and of the equal and inalienable rights of all members of the human family is the foundation of freedom, justice and peace in the world." Persoalan krusialnya adalah sejauh mana implementasi payung hukum tersebut, sama halnya dengan realisasi penerapan beberapa butir deklarasi dalam bidang olahraga, seperti yang dirumuskan oleh UNESCO Bangkok (2012). Disebutkan bahwa: "believes that physical education bestows the experience (of) equality, freedom and a dignifying means for empowerment, particularly for girls and women" (Beutler, 2008: 365).

Pada dasarnya, aneka pembedaan antara pria dan wanita yang terjadi di masyarakat 
Indonesia khususnya cenderung dibentuk oleh masyarakat itu sendiri oleh nilai budaya sehingga masyarakat memberi peran dan kesempatan yang berbeda kepada anak laki-laki dan perempuan. Nilai budaya yang melandasi perlakuan terhadap masing-masing anak semacam itu diwariskan atau diawetkan dari generasi tua ke generasi berikutnya, yang dimulai dari lingkungan keluarga. Masyarakat ikut serta menggiringnya tentang bagaimana seharusnya seorang laki-laki dan perempuan bersikap atau berbuat. Lambat laun sikap, pandangan, dan perlakuan seperti itu melekat menjadi stereotip gender. Nelien \& Busakom (2005:04) menjelaskan bahwa "makna-makna sosial yang diberikan atas perbedaan jenis kelamin secara biologis ini tercakup dalam istilah gender."

Kenyataan di lapangan ditemukan bahwa kecilnya peluang para wanita Indonesia dalam melakukan aktivitas, khususnya aktivitas olahraga sangat terkait dengan masalah pola asuh, budaya, sosial, ekonomi, dan agama. Secara umum, keberadaan olahraga para wanita di Indonesia masih terbilang kelompok 'nomor dua' jika dibandingkan dengan laki-laki. Indonesia yang memiliki budaya majemuk yang dipedomani sebagai aturan kehidupan penggunanya, seringkali budaya itu memperkuat kelanggengan bias gender sehingga sampai sekarang Indonesia masih menghadapi persoalan kesetaraan gender yang konon belum terpecahkan. Muncul pertanyaan, bagaimana sebetulnya proses pola asuh di lingkungan keluarga dan sosialisasi dalam kelangsungan keterlibatan atlet muda wanita dalam cabang olahraga, khususnya cabang bela diri.

\section{METODE}

Penelitian ini dilakukan dengan metode kualitatif dengan studi kasus (Bogdan \& Biklen 2006), dan merupakan studi yang berusaha menyingkap, mendeskripsi, menganalisis, memroyeksi, dan memberikan makna tentang berbagai upaya orang tua dalam model pola asuh yang dilakukan dalam membesarkan dan mendewasakan anak perempuannya sehingga anak memutuskan untuk tetap menggeluti olahraga kompetitif/olahraga prestasi. Penelitian ini ter- golong pada studi kasus karena unik ditinjau dari proses perkembangan dan dampak olahraga prestasi, sehingga memerlukan pendalaman.

Penjaringan data berkaitan dengan persepsi, pendapat, dan keberadaan seseorang dalam banyak hal. Demikian juga aspek-aspek lain yang menyangkut fisik, mental, dan sosial yang terjadi sebelum dan yang sedang dialami oleh unit analisis. Informasi yang dibutuhkan lebih cenderung pada keberadaan masa lalu yang merupakan dampak dari penerapan model pola asuh yang dilakukan orang tua dalam upaya membesarkan dan mendewasakan anakanaknya, sehingga anak mampu memutuskan untuk memilih cabang olahraga prestasi (dalam hal ini olahraga maskulin).

Penelitian berupaya menggali kembali bentuk kehidupan yang dilalui unit analisis sebagai anak perempuan sebelum berkiprah sebagai atlet nasional. Untuk tujuan tersebut, peneliti terlibat langsung dalam proses penelitian (peneliti sebagai instrumen penelitian) dengan melakukan observasi partisipasi, wawancara secara mendalam, pemotretan dokumen dan situasi yang pernah terjadi pada diri sampel, serta diskusi yang mendukung penyempurnaan data. Keseluruhannya dilakukan untuk menghasilkan data yang lengkap dalam penyempurnaan hasil penelitian. Pemilihan latar penelitian dilakukan untuk mengungkap konsep pola asuh yang dilakukan di rumah, di klub, dan di sekolah, serta diperkuat pandangan suami, lingkungan pekerjaan, dan masyarakat terpilih.

Pengumpulan data dilakukan dengan observasi langsung pada keluarga atlet bela diri judo dengan tinggal bersama keluarga unit analisis selama enam bulan. Hal itu dilakukan untuk dapat lebih jelas memotret pola pengasuhan yang dilakukan oleh keluarga. Selain itu, dilakukan wawancara yang bersifat snow ball dengan maksud untuk lebih memahami kondisi seutuhnya dari unit analisis.

Peneliti yang bertindak sebagai human instrument. Oleh karena itu, sebelum peneliti memasuki lapangan telah memiliki catatan mengenai berbagai persiapan, perasaan, harapan, 
dan pandangan terhadap dirinya sebagai kunci dalam pengambilan data (Lincoln \& Guba, 1985:193-194; Patton, 2002). Pengembangan fokus penelitian dilakukan sambil mengumpulkan data, proses seperti ini dikenal dengan “emergent design' (Lincoln \& Guba, 1985: 102). Segala sesuatunya yang berkaitan dengan pengambilan dan pengumpulan data berkembang di lapangan. Beberapa alat pengumpul data yang dpakai dalam mengumpulkan data yaitu, observasi, wawancara, angket terbuka, dan dokumentasi.

Untuk memperoleh dan menjamin tingkat keabsahan data, peneliti mengukur dengan beberapa kriteria keabsahan. Jackson and Drummond (2007:6) mengungkapkan: "The qualitative research design tests trustworthiness via credibility, transferability, dependability, and confirmability."

\section{HASIL DAN PEMBAHASAN}

Dari data yang terkumpul, selanjutnya dilakukan pemetaan data dan pada akhirnya dapat ditemukan beberapa hasil penelitian seperti dideskripsikan berikut.

\section{Analisis Unit Atlet dan Keluarga}

- Unit analisis mulai aktif mengenal judo berawal dari kebiasaan ikut ayahnya, yang kebetulan juga sebagai pelatih nasional judo, bersama dua orang kakaknya, setiap sore pergi ke tempat latihan sambil bermain, kegiatan itu berlangsung sejak kecil. Tidak terasa unit analisis terkondisikan pada apa yang disebut "latihan".

- Atlet ini mulai bertanding dalam pertandingan resmi ketika masih duduk di kelas 5 SD.

- Olahraga yudo menurutnya lebih penting untuk kaum perempuan, karena selain untuk prestasi juga untuk menjaga diri.

- Untuk mampu berhasil sangat penting dukungan orang tua.

- Motivasi berprestasi ditunjukkan dengan latihan yang maksimal dan bertanding dengan upaya maksimal, seperti sebelum bertanding saya harus meningkatkan "anxiety" dengan harapan saya bisa memimpin pertandingan dan membuahkan kemenangan.

\section{Analisis Unit Sekolah}

- Persoalan yang muncul bagi atlet yang sedang bersekolah adalah membagi waktu untuk dua aktivitas besar agar sekolah tidak terganggu akibat latihan. Demikian pula sebaliknya, meski diakui sering terasa capek yang luar biasa. Untuk unit analisis dalam penelitian ini, keduanya berjalan dengan baik, ini terbukti sekarang sudah mampu menyelesaikan S2 dan masih menjadi atlet nasional.

- Siswa ini memiliki sifat agak pendiam dengan fisik yang cukup besar. Meski demikian, dalam pelajaran olahraga mampu melakukan gerakan dengan mudah. Artinya, kecakapan motoriknya cukup luwes.

- Motivasi belajarnya kuat. Hal itu terlihat dari "kesungguhannya dalam belajar dan tidak ingin ketinggalan, sebuah keadaan yang membuat guru-guru heran, bagaimana anak itu bisa mengatur waktunya untuk berlatih, meski sering minta izin akibat kegiatan latihan dan pertandingan yang menyita waktu cukup banyak sehingga ia sering meninggalkan sekolah.

- Pandangan pihak sekolah (dari sisi islami, karena siswa ini bersekolah di sekolah bernuansa Islam) tentang olahraga sah-sah saja, baik ditinjau dari pakaian maupun perkenaan badan antara laki-laki dan perempuan, asal itu pada tempatnya, maksudnya di lapangan olahraga. Bahkan, unit analisis dalam penelitian ini selalu menjadi motivator untuk sisiwa lainnya karena sesuatu yang sangat positif dan penting disosialisasikan kepada perempuan lainnya sehingga ia dijadikan sebagai model dalam menularkan prestasinya kepada yang lain

\section{Analisis Unit Klub}

- Data kualitatif yang dihimpun dari pelatih menyatakan bahwa atlit ini pendiam, baik dan sopan santun dan hormat pada semua orang, atau menghargai orang lain, apalagi pada pelatih. 
- Pelatih yudo menegaskan, khususnya pada tatar Sunda yang kental dengan budaya, bersentuhan saja antara laki-laki dan perempuan tidak dapat diterima. Padahal, dalam yudo "tidak hanya bersentuhan tetapi bahkan berpelukan, selalu terjadi dalam proses latihan."

- Atlet perempuan lebih ulet dalam menekuni latihan, sementara atlet laki-laki memiliki semangat yang lebih tinggi" meski angka "drop-out" atlet perempuan lebih tinggi daripada atlet laki-laki.

- Banyak faktor yang menyebabkan hal itu dapat terjadi, seperti pemilihan olahraga keras yang dikaitkan dengan budaya, sedangkan faktor lainnya yang menyebabkan " $d r o p$ out" atlet perempuan dalam yudo lebih spesifik, yaitu terkait dengan proses pelatihan, terutama "bentuk-bentuk latihannya."

\section{Analisis Unit Masyarakat}

- Reaksi masyarakat terhadap wanita berolahraga (utamanya olahraga keras) masih sering dikaitkan dengan kodrat kewanitaannya. Namun, unit analisis dalam penelitian ini menunjukkan bahwa tidak ada keluhan yang dirasakan sebagai akibat keterlibatannya dalam olahraga yudo, bahkan ia mampu meraih prestasi pada tingkat Asia Tenggara.

- Pola asuhan yang dilakukan oleh orang tua pada anak-anaknya akan menunjukkan warna pada anak di masyarakat karena pada dasarnya anak akan mengidentifikasikan diri pada orang tuanya sebelum mengadakan identifikasi dengan orang lain. Seperti halnya keluarga ini yang berdomisili di tataran Parahyangan, Sunda, yang kental dengan kultur budaya patriarkat, dapat memberikan kesempatan pada anak-anak untuk berkembang meskipun ada nuansa khas, karena sang ayah adalah pembina olahraga.

- Pola pengasuhan yang dilakukan keluarga ini pada anak mereka merupakan pola pengasuhan demokratis layaknya pengasuhan anak lainnya di masyarakat, dan terjadi pada proses yang cukup panjang, dapat menggiring anak pada sifat mempunyai rasa tanggung jawab (responsibility), baik pada diri- nya sendiri, maupun pada lingkungan sekitarnya. Ini sejalan dengan pendapat.

\section{Analisis Unit Suami}

Suami memberi suport sepanjang hari; hal ini terbukti hingga memiliki anak, responden masih aktif dalam mengukir prestasi meski sudah meniti karir juga sebagai pelatih.

\section{Analisis Unit Lingkungan Pekerjaan}

Di lingkungan tempat bekerja, yakni sebagai dosen di FPOK-UPI, responden cukup disenangi. Hal ini terbukti kinerja responden yang cukup baik yang ditunjukkan dengan kemampuannya bekerja sama dengan kolega lainnya, dan jika ada kegiatan melatih, bahkan latihan dalam menghadapi pertandingan, responden mampu membagi waktu antara pekerjaan dan aktivitas di klub.

\section{Pembahasan}

Persoalan pertama dan utama yang dibahas dari hasil penelitian ini adalah bagaimana pengaruh pola asuh yang dilakukan keluarga, klub, dan sekolah sebagai lingkungan anak perempuan ditinjau dari perspektif politik dan kebijakan publik terhadap pemberian kesempatan dan kemudian dampaknhya terhadap partisipasi wanita untuk berolahraga. Jika dilihat pola asuhan yang dilakukan oleh keluarga pada anak perempuannya, orang tua belum sepenuhnya memberi kesempatan yang sama antara anak laki-laki dan perempuan untuk memilih olaharaga prestasi. Kondisi yang sama ternyata tidak hanya ada di Indonesia. Hal serupa juga dirasakan di beberapa negara seperti Eropa, di mana perempuan tertinggal secara serius di belakang laki-laki dalam berolahraga. Vassiliou (2014:3) menegaskan bahwa: more women in Europe participating in sport activities, a lot remains to be done in the sphere of gender equality.Many women are today still unable to find the right environment in which to develop their full potential. In some countries, women lag seriously behind men in access to sport. Dapat dikatakan bahwa, masih banyak perempuan saat ini tidak dapat menemukan lingkungan yang tepat untuk mengembangkan 
potensi mereka sepenuhnya, termasuk potensi dalam prestasi olahraga.

Orientasi nilai terlalu banyak memengaruhi persepsi khalayak umum yang memandang dan mengartikan olahraga itu pada dasarnya "milik kaum lelaki" dan karena itu benar-benar tidak sesuai dan tidak patut dilakukan oleh kaum perempuan. Sejarah perkembangan olahraga, termasuk di Indonesia yang umumnya mengadopsi olahraga dari kelompok masyarakat Barat dan atau masyarakat kolonial sejak zaman pra-kemerdekaan, benar-benar dipasung oleh mindset "masculine sport." Karena itu, halangan utama bagi pengembangan olahraga wanita di Indonesia dalam konteks kesetaraan gender dan implementasi prinsip inklusif, atau olahraga sebagai hak asasi manusia yang sungguh-sungguh pada setiap lapisan masyarakat, khususnya di lingkungan lembaga pendidikan dan organisasi olahraga untuk mengurai simpul ikatan-ikatan psikologis yang berakar pada budaya, yang mendasari sikap dan perilaku masyarakat dalam olahraga. Melalui olahraga kaum laki-laki mengembangkan keterampilan dan kekuatan fisik, ketangguhan mental, dan sifat-sifat "gentlemen" serta semangat satria fair play.

Di sisi lain, sering sekali pola asuhan yang dilakukan bagi anak perempuan berbeda dengan anak laki-laki. Dalam memilih aktivitas olahraga misalnya, keluarga dan masyarakat secara kompak melihatnya dari sisi kecocokan, artinya "ada" olahraga yang cocok untuk kaum laki-laki dan ada pula olahraga yang cocok bagi kaum perempuan. Dengan demikian secara terang-terangan masyarakat telah memilah dan menyempitkan kesempatan berolahraga bagi kaum wanita. Daulton (2013:3) secara terangterangan mengungkapkan adanya perbedaan peran laki-laki dan perempuan, tidak hanya dalam bidang olahraga, akan tetapi dalam banyak hal. Sports have served as an arena for men. Competition served as a means of displaying power and dominance. Since men predominantly held positions of power and dominance in the home, politics, and business, women's main role was to stay at home, support her husband, and focus on raising the family.
Dengan tegas ia mengisyaratkan bahwa lakilaki terutama memegang posisi kekuasaan dan dominasi baik di rumah, politik, dan bisnis, peran utama perempuan hanyalah untuk tinggal di rumah saja, mendukung suaminya, dan fokus pada melayani keluarga.

Isu kesetaraan gender memang mengandung implikasi sosial dan politik adalah bahwa kaum wanita meminta 'bagian' dan perubahan dalam bentuk kesetaraan kesempatan dengan catatan kaum wanitalah yang secara otonom untuk memutuskan dalam kegiatan olahraga yang mana mereka akan berkiprah. Karena itu, isu kesetaraan gender dalam olahraga pada gilirannya mengalami pergulatan untuk melepaskan diri dari nilai-nilai budaya yang untuk membentuk konstruksi sosial baru berupa alokasi fungsi dan peranan wanita di masyarakat (Coakley, 2003). Isu ini jelas sekali apabila ditelaah dari teori strukturalisme fungsionalis yang dikembangkan oleh Levi Strauss (Ahimsa, 2006) dalam sosiologi yang memahami tatanan masyarakat dengan komponen di dalamnya, di mana tiap komponen memainkan peranannya masing-masing untuk mencapai tujuan tertentu, dan dengan maksud tertentu pula.

Pemilihan cabang olahraga tertentu bagi kaum perempuan, seperti cabang judo misalnya, merupakan 'penolakan' olah masyarakat, dengan alasan selama proses latihan ada gerak membanting, mengunci, menyapu kaki lawan supaya jatuh. Kesemuanya itu memang terkesan "keras" dan itu pulalah yang memperkuat kesan olahraga judo itu hanya cocok untuk kaum laki-laki. Belum lagi kesan yang tersirat selama proses latihan yang cukup panjang, ada adegan saling bersentuhan bahkan berpelukan, ketika seorang pelatih akan melatihkan teknik bantingan. Konstruksi nilai sosial inilah yang terjadi, sehingga tidak mengejutkan bahwa selama Orde Baru, meskipun tidak dalam bentuk kebijakan publik yang dikeluarkan oleh lembaga pemerintah atau kebijakan organisasi olahraga, tetapi melalui fatwa yang secara tidak langsung melekat dalam kekuasaan, lewat Ibu Negara pada waktu itu muncul dan beredar 
larangan untuk menyelenggarakan pertandingan gulat bagi wanita.

Dari beberapa alasan seperti di atas, atlet elit perempuan merasaseperti merekamelintasi batas-batasgender dalam melakukan olahraga yang terkesan olahraga laki-laki sehingga banyak yang meninggalkan profesi atletnya. Slater (2010:619-626) menyebutkan: The girls generated a number of different reasons for ceasing to play sport, including losing interest, lack of competence and insufficient time. Girls also reported feeling like they were crossing traditional gender boundaries when playing sport, particularly for sports traditionally classified as 'masculine'. Additional concerns related to team-mates and teasing as well as concerns about appearance and image while playing sport. Terkait dengan Slater, bahwa isu lain yang menyebabkan "drop out" atlet perempuan dalam olahraga keras (masculine sport) lebih terkait dengan proses pelatihan, terutama "bentuk-bentuk latihannya" yang menuntut kekerasan, sehingga pada akhirnya ada kekhawatiran tentang penampilan dan citra saat berolahraga.

Pembahasan lainnya yang bisa dipaparkan terkait dengan terhambatnya prestasi olahraga adalah faktor media yang sangat tidak adil dalam menayangkan berita olahraga, jika ditilik berita olahraga mayoritas diisi oleh prestasi laki-laki. Kane, dkk. (2013:1) berpendapat bahwa cakupan siaran lebih meremehkan olahraga perempuan: media portrayals of sportswomen emphasize femininity/heterosexuality versus athletic competence and argue that such coverage trivializes women's sports. Little research attention has been given to how these portrayals are interpreted by various audiences, including female athletes.

Berangkat dari analisis di atas, citra ketidakpatutan wanita untuk melakoni suatu cabang olahraga berakar dari fakta bahwa aktivitas olahraga bagi parawanita merupakan bagian integral dari keseluruhan relasi kekuatan budaya yang diperankan oleh keluarga dan masyarakat dalam bentuk pola asuh ke anakanaknya. Oleh karena itu, sampai saat ini isu kesetaraan gender dalam olahraga merupakan konflik untuk mengurangi, dan bukan sama sekali menghapus citra kelaki-lakian dalam olahraga, karena sebenarnya memang ada soal kesesuaian yang terbentuk oleh kesepakatan, dan pada gilirannya diakui dan diterima masyarakat.

Dari hasil penelitian dan pembahasan hasil, dilahirkan beberapa proposisi sebagai berikut.

\section{Proposisi ke-1:}

Sistem politik yang selanjutnya dijabarkan dalam kebijakan publik merupakan faktor determinan bagi perkembangan partisipasi wanita dalam olahraga wanita secara nasional. Sementara derajat keberhasilan pengembangannya sangat dipengaruhi oleh kapabilitas manajemen dan ketersediaan sumber daya untuk menjamin kesinambungan dan adaptasi dengan perubahan. Meskipun demikian, sistem nilai dan budaya masyarakat yang masih kuat berorientasi pada budaya patriarkhi merupakan faktor yang sangat berpengaruh pada pencitraan kepatutan wanita berolahraga sehingga pembangunan olahraga nampaknya perlu memperhitungkan nilai-nilai budaya.

\section{Proposisi ke-2:}

Semakin banyak pengalaman, pengetahuan dan bahkan kecakapan berolahraga di kalangan sebuah keluarga, terutama pihak ayah, maka semakin besar peluang yang diperoleh, khususnya bagi anak-anak wanita untuk berpartisipasi dalam olahraga. Faktor seorang figur di lingkungan atau sekitar keluarga dengan penonjolan performa merupakan model yang efektif untuk membangkitkan motivasi anak untuk berolahraga.

\section{Proposisi ke-3:}

Proses pembinaan wanita dalam olahraga yang potensial untuk berprestasi lebih banyak didorong oleh kalkulasi peluang memperoleh medali, yang hasilnya sekaligus membangun citra positif bagi klub atau daerah, sementara untuk memperkuat dukungan keluarga dan semua pengorbanan atlet disediakan unsur pengukuh hadiah material. Kesemuanya itu masih 
terbilang bukan upaya tulus untuk memberikan peluang bagi wanita guna memperoleh manfaat dari kegiatan olahraga, tetapi lebih cenderung sebagai tindak manipulatif untuk menjadikan wanita sebagai objek belaka. Kian besar peluang wanita untuk berprestasi dalam suatu cabang olahraga, kian besar potensi mereka hanya dijadikan objek belaka.

\section{PENUTUP}

Secara umum kesimpulan yang diperoleh menunjukkan interelasi sejumlah faktor dalam pola hubungan yang kompleks, yakni proses sosialisasi anak wanita usia muda ke dalam olahraga berawal dari lingkungan keluarga. Struktur keluarga yang utuh dengan ciri memiliki komitmen yang kuat dalam olahraga, ikatan emosional yang kuat, dengan asuhan yang hangat dan diterima (acceptance) hingga melahirkan putera puteri yang patuh (obedient). Sementara ayah memainkan peranan paling dominan dalam proses sosialisasi tersebut di tengah pasungan budaya patriarkhi yang juga menjelmakan dunia olahraga laki-laki (masculine sport), meskipun kemudian pihak ibu banyak terlibat untuk memberikan dukungan dan pengorbanan.

Faktor lingkungan keluarga (eco-family) juga berpengaruh untuk ikut membentuk sikap positif anak wanita usia muda terhadap olahraga dengan munculnya idola dari saudara sekandung atau keluarga lain. Lingkungan pada tingkat messo, khususnya fasilitas olahraga yang memberi kenyamanan membangkitkan sensasi yang menyenangkan bagi anak untuk berolahraga. Lingkungan makro memainkan peranan melalui media masa yang membentuk citra positif wanita berolahraga, berikut kebijakan publik dan landasan hukum, yang memberikan kepastian masa depan atlet melalui penetapan sistem penghargaan.

\section{UCAPAN TERIMA KASIH}

Peneliti merasakan banyak pihak yang membantu penelitian ini. Oleh karena itu, penulis mengucapkan terima kasih dan penghargaan yang tinggi kepada semua pihak, terutama Dr. Yunyun Yudiana, Dr. Bambang
Abduljabar, M.Pd., Dede Rohmat Nurjaya, M.Pd., Yusuf Hidayat, M.Si. dan Ira Purnamasari, M.Pd. dari Universitas Pendidikan Indonesia, dan semua pihak yang telah banyak memberikan kontribusi, baik secara konseptual maupun teknis sehingga penelitian ini dapat diselesaikan dengan baik. Mudah-mudahan amal baik yang telah Ibu Bapak berikan mendapat imbalan yang sesuai dari Tuhan Yang Maha Kuasa. Terakhir, penulis juga mengucapkan terima kasih kepada pengelola Jurnal Cakrawala Pendidikan dari LPPMP Universitas Negeri Yogyakarta yang telah berkenan mempublikasikan artikel ilmiah ini.

\section{DAFTAR PUSTAKA}

Ahimsa P. 2006. Strukturalisme dan Teori Sosiologi L'evi Strauss. Yogyakarta: Insight Reference.

Anderson, E. 2005. "In the Game: Gay Athletes and the Cult of Masculinity". Albany, NY: State University of New York.

Beutler, K.D., 2008. "Empowering Girls and Women through Physical Education and Sport. Advocacy Brief. Bangkok: UNESCO Bangkok., 2012.

Bogdan, R. C., \& Biklen, S. K. 2006. "Qualitative Research in Education: An Introduction To Theory and Methods". 4th ed., Needham Heights, MA: Allyn \& Bacon.

Clasen, P.R.W. 2001. "The Female Athlete: Dualisms and Paradox in Practice". Women and Language. 24 (2), 36-41.

Coakley J. J. 2003. Sport in Society. St Louis: Times Mirror College Publishing.

Duncan, M., and Messner, M. 2000. Gender in Televised Sports: 1989, 1993 and 1999. AAF, Los Angeles. (http://www.aafla.org/Publications/Publications.htm).

Jackson, R.L., Drummond, D.K., \& Camara, S. 2007. "The Qualitative Research Design Test Trust Worthiness Via Credibility, Tranferability, Dependabilityand Confir- 
mability". Qualitative Research Reports in Communication Journal. 8 (1), 21-28.

Daulton, Juli. 2013. "Equality in the Intercollegiate sport". Journal The Evolution of Gender, Volume 1, Issue 1, Article 7, Page 3. Portland University, jdaulton@pdx.edu.

Kane, Mary Jo, Nicole M. LaVoi, \& Janet S. Fink, 2013. "Exploring Elite Female Athletes' Interpretations of Sport Media Images: A Window Into the Construction of Social Identity and "Selling Sex" in Women's Sports”. Journal of Communication and Sport. Pp 1-15.

Knoppers, A., \& Anthonissen, A. 2003. "Women's Soccer in the United States and the Netherlands: Differences and Similarities in Regimes of Inequality". Sociology Sport Journal. 20. 351-370.

Knoppers, A., \& Elling, A. 2001a. “Organizingmasculinities and Femininities: The Gendered Sporting Body". Steenbergen J., De Knop P., and Elling A. H. F. (eds.), "Values and Norms in Sport. CriticalReflections on the Position and Meanings of Sport in Society".Meyer \& Meyer, Oxford, pp. 171-194.

Lincoln, Y.S., \& Guba, E.G.1985. Nataralistic Inquiry. Beverly Hills, CA: Sage.

Luisa, B. 2011. "The U.N. Issues in the U.S. Ratification Debate, Congressional Reseacrh Service". Convention on the Elimination of All Forms of Discrimination Against Women (CEDAW).

Lutan. R. 2004. "Olahraga Kebijakan dan Politik; sebuah analisis". Proyek Pengembangan \& Keserian Kebijakan Olahraga. Dirjen Olahraga Departemen Pendidikan Nasional.

Messner, M. A. 2002. Taking the Field: Women, Men and Sports. Minneapolis, MN: University of Minnesota Press.
Messner, M. A., \& Sabo, D.1990. "Toward a Critical Feminist Reappraisal of Sport, Men, and the Gender Order", dalam M. A. Messner \& D. Sabo (Eds.). Sport, Men and The Gender Order: Critical Feminist Perspectives. (pp. 1-15). Champaign, IL: Human Kinetics.

Messner, Michael, A. \& Chery Cooly. 2010. "Gender In Televised Sport". Journal Center For Feminis Research. Pp 1-35. Reprented by permission of the authors and the USC center for feminist.

Nelien \& Busakom, 2005. Meningkatkan Kesetaraan Gender. dalam Aksi Penanggulangan Pekerja Serta Perdangangan Perempuan dan Anak. Organisasi Perburuhan Internasional (ILO). Program Penghapusan Pekerja Anak.

Patton, M.Q. 2002. "Qualitative Evaluation and Research Method". Newbury Park., CA: Sage.

Slater, Amy. 2010. "Uncool to Do Sport": A Focus Group Study of Adolescent Girls' Reasons for Withdrawing from Physical Activity”. JournalPsychology of Sport and Exercise. Volume 11, Issue 6, Pages 619-626.

The First CEDAW, 2009, "Impact Study: Final Report, York University Centre for Feminist Research and the International". Women's Rights Project, available at. http://www.iwrp.org/CEDAW_Impact_S tudy.htm.

Undang-Undang No. 3 Tahun 2005, Sistem Keolahragaan Nasional. Jakarta: Kementerian Negara Pemuda dan Olahraga Republik Indonesia.

Vassiliou, Androulla. 2014. "EU Commissioner for Education, Culture, Multilingualism, Youth and Sport". Journal Gender Equality in Sport. page 3. 